\title{
Charles Frederick Hartt: romântico por formação e realista por profissão
}

\section{Charles Frederick Hartt: a romantic by education and a realist by trade}

\author{
Karoline Viana Teixeira \\ Doutoranda, Programa de Pós-Graduação em História/Universidade Federal do Ceará. \\ karolineteixeira@gmail.com
}

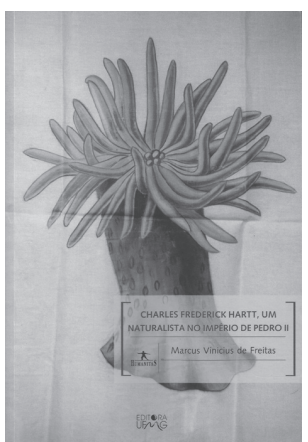

FREITAS, Marcus Vinicius de. Charles Frederick Hartt, um naturalista no império de Pedro II. Belo Horizonte: Editora UFMG. 2002. 282p.

Tos últimos anos, pesquisadores de diversas áreas têm-se dedicado 1 à temática dos viajantes naturalistas que esquadrinharam o Brasil ao longo do século XIX. Desde o fim do exclusivismo português, a ex-colônia tornou-se destino estratégico não só para o comércio internacional, cioso de novos mercados, como também para academias e centros de saber que para cá enviavam seus representantes a fim de pesquisar biomas, fauna, flora e minerais até então vedados ao olhar estrangeiro. Um deles foi o geólogo americano Charles Frederick Hartt (1840-1878), cuja trajetória relevante, porém pouco conhecida, é abordada pelo estudo de Marcus Vinicius de Freitas.

Fruto de sua tese de doutorado junto ao Departamento de Estudos Portugueses e Brasileiros da Brown University, o livro analisa as incursões de Hartt no território brasileiro - como assistente de Louis Agassiz na Expedição Thayer; em duas viagens por conta própria, como membro da Expedição Morgan; e, por fim, a convite do Império brasileiro para chefiar a Comissão Geológica. Apesar da pretensão de implantar aqui um serviço de estudos geológicos, esta última comissão foi abreviada por questões políticas e pela morte prematura de Hartt, vítima de febre amarela no Rio de Janeiro. O americano dedicou 13 dos seus 38 anos de vida aos estudos do Brasil, abordando a formação geológica da América do Sul, como também aspectos da etnografia indígena, plantas e animais tropicais, língua tupi, entre outros.

Karen Lisboa (1997) define a viagem científica empreendida no século XIX como uma etapa do processo do conhecimento norteado por um "projeto ilustrado", em que a atração pelo exótico, a pesquisa naturalista e o gosto pela errância se coadunam com interesses de esfera pública, como o desenvolvimento da ciência, a formação de coleções para museus de história natural e a investigação de recursos potencialmente exploráveis. Hartt vem pela 
primeira vez ao Brasil em 1865, na fase áurea do Segundo Reinado. O momento de estabilidade política e pujança econômica permitiram a arregimentação de forças em torno de um projeto ideológico de nação. A busca de uma origem indigenista, o estabelecimento de uma imagem harmônica para um país neófito permeado por contradições e o incentivo a instituições científicas e literárias foram balizadores importantes para os naturalistas estrangeiros que vieram para o Brasil nesse período.

Nomes como Eschwege, Martius, Spix, Saint-Hilaire, Agassiz e o próprio Hartt - este em certa medida, como o estudo busca demonstrar -, imbuídos de uma formação idealista que percebia a história natural como uma teologia natural, contribuíram para dar uma feição eminentemente romântica às ciências naturais aqui praticadas. A acepção do romantismo nesse caso vai além de um estilo literário, tratando-se antes de uma visão de mundo estruturante para uma nação que buscava se firmar como um império nos trópicos. Assim, como afirma o autor, "num momento em que uma visão racional e desencantada da natureza se afirmava mundo afora, sobretudo através da revolução darwinista, as ciências naturais ganham impulso na Brasil através de um estatuto romântico, através de uma visão teológica e finalista da natureza" (p.38).

O livro problematiza as matrizes ideológicas de Hartt e a importância do seu legado para a institucionalização das ciências no Brasil. Com texto fluente, que articula fontes escritas e imagéticas de arquivos do Brasil e dos EUA, o trabalho combina capítulos temáticos com uma narrativa cronológica, permitindo a condução de análises e digressões na descrição da trajetória intelectual do naturalista. Após contextualizar no primeiro capítulo o momento social e político acima citado, Marcus Vinicius de Freitas aborda a formação de um naturalista no período - levando em conta as especificidades do meio intelectual norte-americano, uma ex-colônia como o Brasil que à época sequer completara o centenário de independência. O autor faz ainda um paralelo entre as políticas de incentivo cultural e acadêmico no Brasil e nos EUA.

O terceiro capítulo investiga o estatuto dos textos produzidos por Hartt, localizando sua escrita e suas análises do Brasil em uma zona de transição entre as matrizes intelectuais dos fatalistas (entre eles seu mentor, Louis Agassiz) e dos evolucionistas (no esteio do inovador A origem das espécies, de Charles Darwin), tornando Hartt "o último representante de um certo tipo de naturalistas viajantes, e um dos primeiros cientistas da nova estirpe" (p.98). Ainda que com menor fôlego, o quarto capítulo volta-se para a análise do legado pictórico do naturalista, retomando o ritmo nos capítulos finais sobre o estudo das comunidades indígenas e a relação de Hartt com as instituições científicas brasileiras, ao assumir a Seção de Geologia do Museu Nacional em sua derradeira incursão ao Brasil.

A principal conclusão desse estudo é que a obra de Hartt transita entre as duas principais correntes intelectuais do século XIX, no livro personificadas por Agassiz e Darwin. O primeiro era o expoente da tradição romântica nas ciências naturais, que percebia cada espécie viva como uma criação única, sem elos entre si, cujo eventual desaparecimento só poderia ser explicado pela ocorrência de desastres naturais, definidos pelo plano geral da criação. Darwin, por sua vez, percebia a natureza sob um sentido evolutivo, em que os seres passam por processos de transformação e adaptação para sobreviver ao meio, determinando, assim, o surgimento ou o desaparecimento de espécies. Tais modificações não seriam, portanto, 
comandadas por um desígnio divino, mas seriam parte constituinte da dinâmica da vida na Terra. A própria Expedição Thayer, que permitiu o primeiro contato de Hartt com o Brasil, está no cerne da disputa entre catastrofistas e evolucionistas. Assim como outros cientistas buscavam provas para corroborar a tese evolutiva, Agassiz buscava comprovar a ocorrência de drifts nas formações geológicas brasileiras para suportar sua tese, o que posteriormente se mostrou equivocado.

Hoje sabemos qual concepção prevaleceu, mas é preciso atentar para o fato de que a ciência, em seu "fazer-se", configura-se em um campo de incertezas, o que torna Hartt um "romântico por formação e realista por profissão", segundo o autor. Apesar de reconhecer que o campo intelectual na segunda metade do século XIX ainda não era bem delimitado e que as ciências naturais sofriam a influência de outras searas, como a história e a literatura, Freitas constrói sua argumentação de forma anacrônica em vários momentos, como se a corrente catastrofista fosse menos "científica" que a evolucionista, quando na verdade se tratava de matrizes intelectuais distintas e, à época, igualmente válidas. Isso faz com que o autor apresente Hartt como alguém influenciado por uma teoria já defasada na origem, que, mesmo percebendo a falta de evidências sobre a ocorrência de drifts, não conseguia desvencilhar-se completamente da ligação intelectual e pessoal com seu mentor, Agassiz.

É pelo mesmo motivo que o autor adota um tom lamentoso ao analisar a principal obra de Hartt, Geologia e geografia física do Brasil. Ao identificar ali a presença de elementos romantizados, típicos de um relato de viagem, Freitas afirma que tal forma narrativa "encontra-se plenamente justificada na tradição de textos da qual o autor tende a se afastar, mas à qual ainda está ligado de forma indelével" (p.87), como se isso fosse um demérito para seu estudo. Mesmo admitindo que não se pode falar de uma precedência entre ficcionistas e não ficcionistas, é recorrente a visão de que a obra de Hartt não alcançaria a plenitude de um texto científico por conta da formação equivocada do geólogo. É como se ele cobrasse de Hartt uma postura que para nós só é possível diante do distanciamento temporal, fazendo com que seus argumentos se tornem contraditórios diante da tese que defende. Seria de bom alvitre que o autor procedesse a uma revisão desses trechos à luz da historiografia atual, a fim de eliminar tais contradições e preservar a grandeza das contribuições que esse estudo oferece ao leitor.

\section{REFERÊNCIAS}

LISBOA, Karen Macknow.

A Nova Atlântida de Spix e Martius: natureza e civilização na Viagem pelo Brasil (1817-1820). São Paulo: Hucitec. 1997. 